Original Article

\title{
Spatio-temporal variability in the Cladocera assemblage of a subtropical hypersaline lagoon
}

\author{
Variabilidade espaço-temporal da assembleia de Cladocera de uma lagoa \\ hipersalina subtropical
}

\author{
J. C. L. Rosa ${ }^{\mathrm{a}, \mathrm{b} *}$ (D) L. L. Batistac and W. M. Monteiro-Ribas ${ }^{\mathrm{d}}$ \\ a ONG Nossa Laguna Ciência e Vida-NLCV, São Pedro da Aldeia, RJ, Brasil

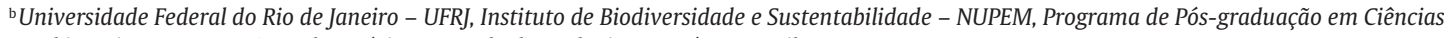 \\ Ambientais e Conservação, Laboratório Integrado de Zoologia, Macaé, RJ, Brasil \\ c Universidade Federal do Rio de Janeiro - UFRJ, Instituto de Biodiversidade e Sustentabilidade - NUPEM, Programa de Pós-graduação em Ciências \\ Ambientais e Conservação, Laboratório de Invertebrados, Macaé, RJ, Brasil \\ ${ }^{\mathrm{d}}$ Instituto de Estudos do Mar Almirante Paulo Moreira, Departamento de Oceanografia, Divisão de Ecossistemas Marinhos, Arraial do Cabo, RJ, Brasil
}

\begin{abstract}
Cladocera represent an important zooplankton group because of their seasonal prominence in terms of abundance and their contribution in controlling primary production (phytoplankton). On a global scale, there are few studies on Cladocera in hypersaline environments. The present work aims to evaluate the spatio-temporal variation of the Cladocera assemblage across a salinity gradient in the habitats of the Araruama Lagoon. Samples were collected in random months over a period of four years at 12 fixed stations in the Araruama Lagoon using a WP2 plankton net equipped with a flow meter. Our results do not reveal significant influence of the tide and seasonal variation as factors affecting the Cladocera assemblage. Five Cladocera species were found in the Araruama Lagoon, only in stations 11 and 12 where they reached an average of 1,799 $\pm 3,103$ ind. $\mathrm{m}^{-3}$. The mean of the Shannon Diversity Index was $0.45 \pm 0.2$. The species that stood out in terms of frequency and abundance were: Penilia avirostris (frequency of occurrence: $71 \%$ ), followed by Pseudevadne tergestina (41\%). The same species also stood out in terms of relative abundance, Penilia avirostris (87\%) and Pseudevadne tergestina (11\%). The absence of Cladocera in the innermost parts of the lagoon suggests that their entrance to these locations is possibly inhibited by the salinity and temperature gradient of the lagoon, being the main factors influencing the dynamics of the Cladocera assemblages.
\end{abstract}

Keywords: Araruama lagoon, Penilia avirostris, salinity, temperature.

\begin{abstract}
Resumo
Os cladóceros representam um importante grupo de zooplâncton, devido ao seu destaque sazonal em termos de abundância e à sua contribuição no controlo da produção primária (fitoplâncton). Em escala global, há poucos estudos com Cladocera em ambientes hipersalinos. $O$ presente trabalho tem como objetivo avaliar a variação espaço-temporal da assembleia de Cladocera em um gradiente de salinidades da Lagoa de Araruama. As amostras foram coletadas em meses aleatórios, durante um período de quatro anos, em 12 estações fixas na Lagoa de Araruama, utilizando uma rede de plâncton WP2 equipada com um fluxômetro. Os nossos resultados não revelam uma influência significativa da maré e da variação sazonal como fatores que afetam a assembleia de Cladocera. Cinco espécies de Cladocera foram encontradas na Lagoa de Araruama. A assembleia apresentou maior densidade absoluta estações 12 e 11, atingindo uma a média de $1.799 \pm 3.103$ inds $^{-3}$. A média do Índice de Diversidade de Shannon foi de 0,45 $\pm 0,2$. As espécies que se destacaram em termos de frequência e abundância foram: Penilia avirostris (frequência de ocorrência: $71 \%$ ), seguida de Pseudevadne tergestina (41\%). As mesmas espécies também se destacaram em termos de abundância relativa Penilia avirostris (87\%) e Pseudevadne tergestina (11\%). A ausência de Cladocera nas partes mais interiores da lagoa sugere que a sua entrada nestes locais é possivelmente inibida pela salinidade e gradiente de temperatura da lagoa, sendo os principais fatores que influenciam a dinâmica da assembleia de Cladocera.
\end{abstract}

Palavras-chave: Lagoa de Araruama, Penilia avirostris, salinidade, temperatura.

\section{Introduction}

Cladocera (Crustacea, Branchiopoda) is an important group of zooplankton (Silva and Perbiche-Neves 2017; Debastiani-Júnior, et al., 2016), although it is not always the most abundant throughout the year, on some occasions it may stand out in numerical importance and thus contribute to top-down control because it is a herbivorous group

*e-mail: judsoncruz@yahoo.com.br

Received: April 9, 2020 - Accepted: September 22, 2020 
(Sommer and Sommer, 2006). However, Cladocera can also feed on other organisms, such as bacteria (HayashiMartins et al., 2017).

In a marine environment the Cladocera Penilia avirostris Dana, 1849 is one of the most abundant zooplankton species in tropical, subtropical and temperate waters (Rose et al., 2004), while the species Evadne spinifera P.E. Müller, 1867, Pseudevadne tergestina Claus, 1877, Pleopis polyphemoides (Leuckart, 1859) and Pleopis schmackeri (Poppe, 1889) are also common in tropical regions (Ramirez, 1981; Monteiro-Ribas et al., 2013). In addition to food availability, temperature and salinity are some of the main factors that may affect the spatiotemporal distribution of zooplankton (Wooldridge and Deyzel, 2009; Monteiro-Ribas et al., 2006).

The Araruama Lagoon is located in the state of Rio de Janeiro, Brazil and presents a high salinity, and a low depth (1.2 to 5.9 meters). Hypersaline environments with salinity between 41 and 50 are generally characterized by low richness and low abundance of the zooplankton community (Buskey et al., 1998). In these environments few species can survive due to high salinities. Currently, the Araruama lagoon presents salinity between 42 and 53, (Rosa et al., 2016) however, salinities twice the values registered in the sea have already been reported (Coutinho et al., 1999). Both depth and salinity are known to limit other organisms such as fish fingerlings, which generally present a preference for locations with milder salinity and places with greater depths (Castro et al., 1999; Rosa et al., 2016).

In addition to the high salinity, another factor observed in the Araruama lagoon is the input of untreated domestic sewage from the municipalities around the lagoon (Pereira, 2007). The entry of sewage into the lagoon has caused a decrease in salinity (Rosa et al., 2016) and an increase in nutrients (Souza et al., 2003). Therefore, the lagoon turned into a eutrophic environment, which can affect fisheries, salt extraction and tourism (Pereira, 2007). The Araruama Lagoon is an important environment since it is one of the largest hypersaline lagoons in the world (Coutinho et al., 1999) and may help to better understand the effects of salinity on the Cladocera assemblage. The present study aims to evaluate the spatio-temporal variation of the Cladocera assemblage across salinity and temperature gradients in the Araruama Lagoon. We hypothesized that: 1) low Cladocera density would occur in places where the lagoon's salinity and temperature are higher than the sea's; 2 ) spatial and temporal variation would occur, correlated with temperature and salinity.

\section{Material and Methods}

\subsection{Study area}

The Araruama lagoon is located between the latitudes of $22^{\circ} 40^{\prime}$ and $22^{\circ} 57^{\prime} \mathrm{S}$ and longitudes of $42^{\circ} 00^{\prime}$ and $42^{\circ} 23^{\prime} \mathrm{W}$ (Figure 1). It is a $210 \mathrm{~km}^{2}$ ecosystem (Castro et al., 1999) connected to the sea by the Itajuru channel, and extends over five municipalities, Araruama, Arraial do Cabo, Cabo Frio, São Pedro da Aldeia and Iguaba. Since the decade of the 80s, the Araruama Lagoon has been suffering from sewage discharge (Pereira, 2007), caused by the increase of visitors in summer (approximately five times the normal population of the region) and by the growth of the resident population of Araruama and the neighboring cities (Coutinho et al., 1999).

\subsection{Sampling}

Salinity, temperature, Cladocera abundance and composition were obtained at 12 strategic sites along

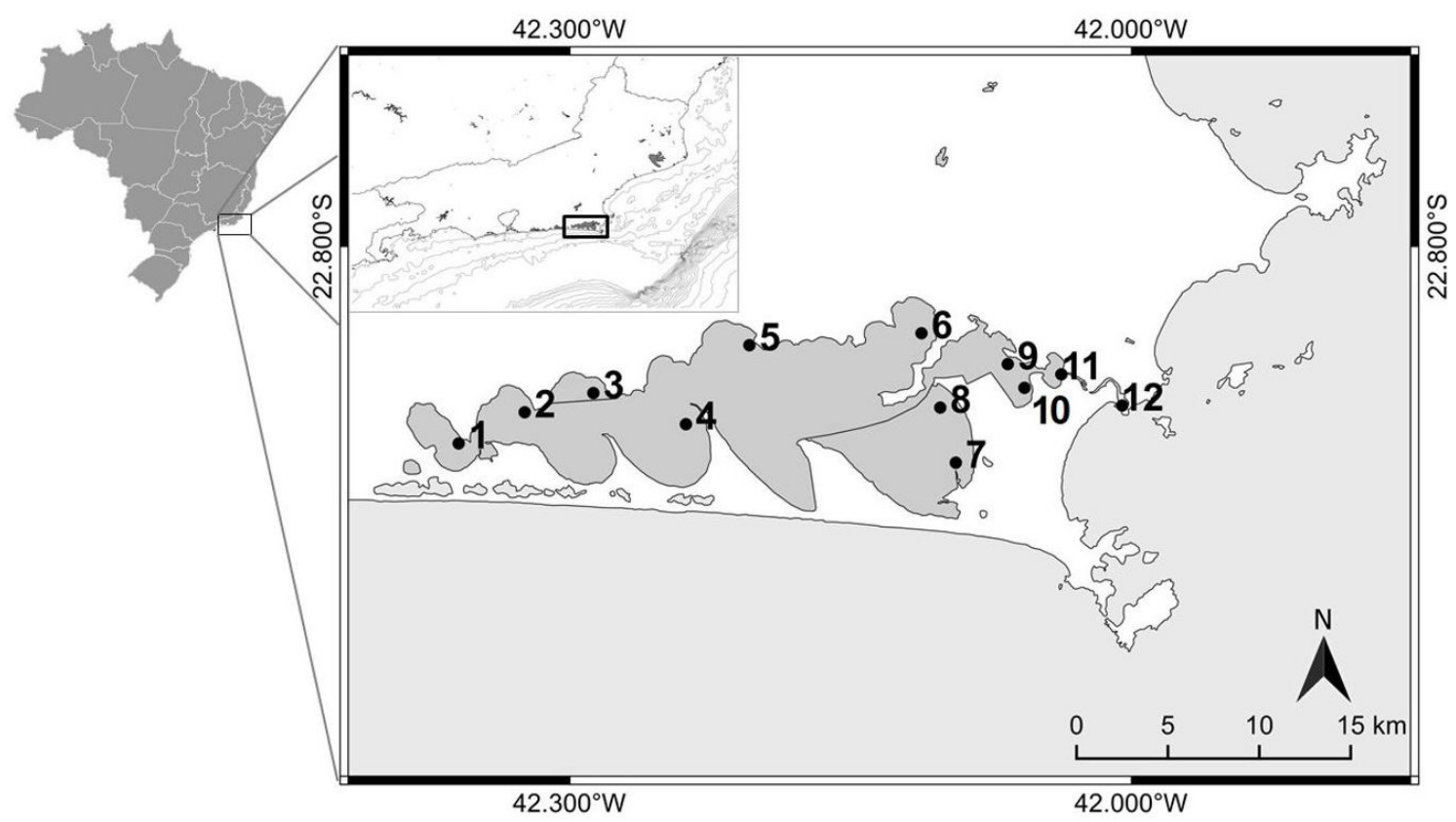

Figure 1. Map of the Rio de Janeiro state coast highlighting the 12 sampling stations in Araruama lagoon. 
the shore of the lagoon: 1- Excursionistas, 2- Araruama Centro, 3- Barbudo, 4- Acaíra, 5- Iguaba Grande, 6- São Pedro d'Aldeia, 7- Monte Alto, 8- Boqueirão, 9- Area 2, 10 Siqueira, 11- Palmeiras, 12- Boca da Barra (Figure 1 and Table 1). Sub-surface salinity and temperature were measured with a refractometer and a portable oximeter (Hanna HI9146-04), respectively. Further details on temperature and salinity can be found in Rosa et al. (2016). Samples were collected in random months over a period of four years (2010 to 2013). It was not possible to standardize the tide at the sampling moments, which ranged between ebb and flood, but all collections were performed in the morning (Table 2). A total of seventeen collections were conducted, obtaining a total of 144 samples of zooplankton by means of horizontal surface hauls with $200 \mu \mathrm{m}$ mesh nets each with a $60 \mathrm{~cm}$ diameter opening and fitted with a flowmeter (in 2010 and 2011 there were no collections in station 9 and 10). Immediately after their collection, samples were fixed in a $4 \%$ formalin solution diluted in water from the lagoon and previously neutralized with sodium tetraborate. In the laboratory, all the samples were sub-sampled with a Stempel pipette. The qualitative and quantitative analyses of the zooplankton samples were performed at the lowest possible taxonomic level, using a stereomicroscope. Identification and species ecology were based on the works of Boltovskoy (1981, 1999). The density of Cladocera taxa was expressed as the number of individuals per cubic meter (ind $\mathrm{m}^{-3}$ ).

\subsection{Data analysis}

The Cladocera assemblage was evaluated using the results of density (Cladocera. $\mathrm{m}^{-3}$ ), relative abundance (\%), frequency of occurrence (\%) and diversity indices. Diversity indicators were used to detect possible variations in the composition and structure of the assemblage:
Shannon-Wiener Diversity Index ( $\left.\mathrm{H}^{\prime}\right)$ and Equitability (J'). The representative dendrogram of the cluster analysis (Group Average) was carried out with the data of the density of the species present in the samples. The data were $\log$ transformed $(\log (x+1))$ to minimize the influence of the most abundant species (Field et al., 1982). The similarity percentages breakdown (SIMPER) procedure (Clarke and Gorley, 2015) was used to assess the average percent contribution of individual variables (species) to the dissimilarity between sampling events at different stations, based on a Bray-Curtis dissimilarity matrix. In this analysis, a correlation matrix was used and the axes were selected according to the Broken Stick Model criteria (Legendre and Legendre, 1998). Also, an analysis of variance (Two-Way ANOVA) with tidal variation (flood and ebb) and season (spring, summer, autumn and winter) was performed to evaluate the spatial and temporal variation of the environmental variables. Finally, we used a linear correlation to investigate the temporal variation in the relative abundance of Cladocera in relation to temperature and salinity.

\section{Results}

Within the study period, temperature showed an overall average of $27 \pm 2.7{ }^{\circ} \mathrm{C}$. Temperature ranged in the area from $21{ }^{\circ} \mathrm{C}$ in October 2010 (station 12) to $32{ }^{\circ} \mathrm{C}$ in January 2010 (station 8). Salinity showed an overall average of $45 \pm 5.5$ and ranged from 36 in December 2013 (station 12) to 53 in February 2010 and June 2013 (stations 1, 3, 4, 6, 7 and 8) (Figure 2). The result of the Two Way ANOVA test showed a significant temperature variation throughout the different seasons ( $F=59.44$; $\mathrm{p}=8.65 \mathrm{e}-12)$ and time $(\mathrm{F}=126.26 ; \mathrm{p}=<2 \mathrm{e}-16)$ (Figure 3 and Table 3). The result of the Two Way ANOVA test also

Table 1. Latitude, longitude, and station depth over the data collection period.

\begin{tabular}{|c|c|c|c|c|c|c|}
\hline Stations & 1 & 2 & 3 & 4 & 5 & 6 \\
\hline Latitude & $22^{\circ} 53^{\prime} 10$ & $22^{\circ} 54^{\prime} 56$ & $22^{\circ} 50^{\prime} 47$ & $22^{\circ} 51^{\prime} 10$ & $22^{\circ} 53^{\prime} 42$ & $22^{\circ} 52^{\prime} 42$ \\
\hline Longitude & $42^{\circ} 06^{\prime} 08$ & $42^{\circ} 05^{\prime} 38$ & $42^{\circ} 06^{\prime} 44$ & $42^{\circ} 12^{\prime} 15$ & $42^{\circ} 14^{\prime} 17$ & $42^{\circ} 17^{\prime} 15$ \\
\hline Depth/meters & 2.3 & 1.4 & 2.2 & 3.7 & 5.9 & 3.4 \\
\hline Stations & 7 & 8 & 9 & 10 & 11 & 12 \\
\hline Latitude & $22^{\circ} 53^{\prime} 19$ & $22^{\circ} 54^{\prime} 19$ & $22^{\circ} 4^{\prime} 37$ & $22^{\circ} 52^{\prime \prime} 32$ & $22^{\circ} 52^{\prime} 6$ & $22^{\circ} 53^{\prime} 6$ \\
\hline Longitude & $2^{\circ} 19^{\prime} 27$ & $42^{\circ} 21^{\prime} 34$ & $42^{\circ} 4^{\prime} 44$ & $42^{\circ} 3^{\prime} 26$ & $42^{\circ} 2^{\prime} 15$ & $42^{\circ} 0^{\prime} 18$ \\
\hline Depth/meters & 2.1 & 1.2 & 1.2 & 1.0 & 2.0 & 3.5 \\
\hline
\end{tabular}

Table 2. Tidal variation during the study.

\begin{tabular}{cccccccccc}
\hline Month/Year & Feb.10 & Mar.10 & May.10 & Jun.10 & Jul.10 & Oct.10 & Nov.10 & Dec.10 \\
\hline Tide & flood & flood & flood & flood & flood & ebb & ebb & ebb \\
\hline Month/Year & Jan.11 & Feb.11 & Mar.11 & Oct.12 & Dec.12 & Mar.13 & Jun.13 & Dec.13 \\
\hline Tide & flood & ebb & ebb & flood & flood & flood & flood & flood \\
\hline
\end{tabular}


showed a significant salinity variation throughout the different seasons $(F=5.816 ; \mathrm{p}=4.46 \mathrm{e}-07)$ and time $(\mathrm{F}=8.678$; $\mathrm{p}=0.00408$ ) (Figure 4 and Table 4 ). The Cladocera were present only in stations 11 and 12 where they reached an average of $1799 \pm 3103$ ind. $\mathrm{m}^{-3}$ (the presence of Cladocera was not registered in any other station than 11 and 12). No significant differences in cladecera abundance were found when comparing different tides in Araruama lagoon (Table 5). During the study period a total of 3 families and 5 taxa of Cladocera were identified and registered: Penilia avirostris, Pseudevadne tergestina, Evadne spinifera, Pleopis polyphemoides and Pleopis schmackeri. The Cladocera density showed a high seasonality, with average values

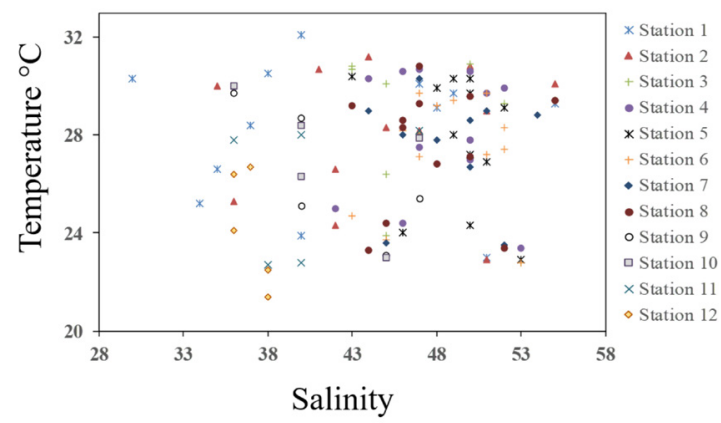

Figure 2. TS-diagram. At the 12 collection stations.
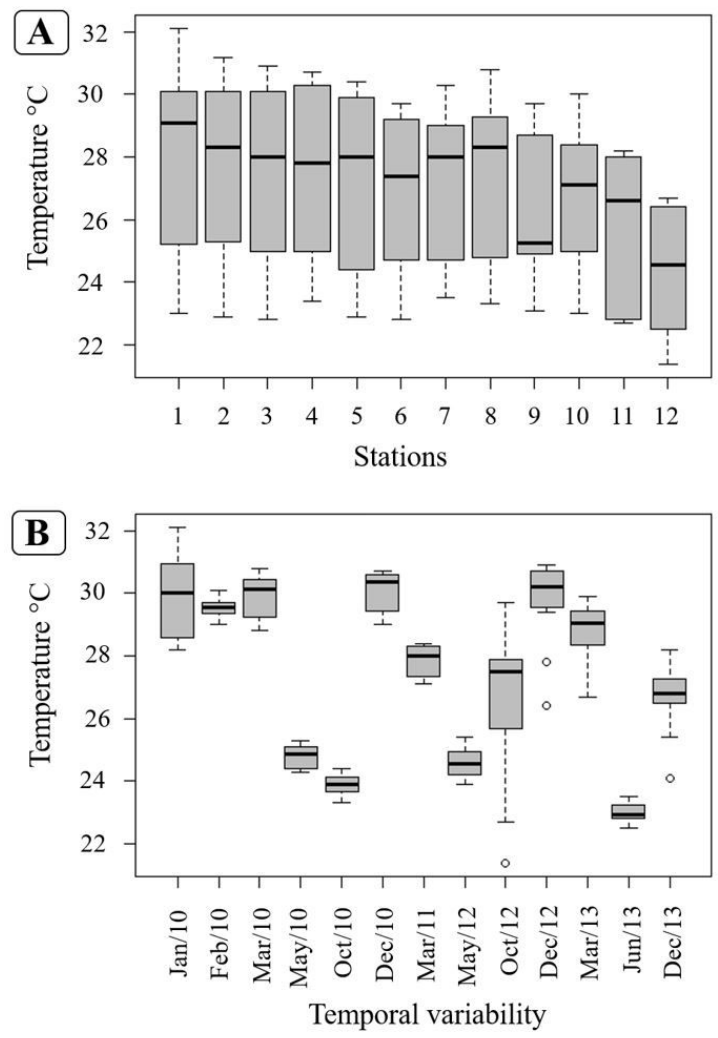

Figure 3. BoxPolt of temperature presented from means and standard deviation, spatial variation (A) and temporal variation (B). of $53 \pm 321$ ind. $\mathrm{m}^{-3}$ and ranging from 0 to 4,575 ind. $\mathrm{m}^{-3}$ with peaks occurring in autumn, summer and winter (Figure 3). The linear regression showed no significant results between temperature $(\mathrm{r}=-0.3930 ; \mathrm{p}=0.2063)$ and salinity $\left(r^{2}=0.0243 ; p=0.6283\right)$ in relation to the Cladocera density. Our results do not reveal significant influence of the tide and seasonal variation as factors affecting the Cladocera assemblage (ANOVA), tide ( $\mathrm{F}=1.807, \mathrm{P}=0.219$ ), seasons $(\mathrm{F}=0.465, \mathrm{P}=0.714)$ and interaction between tide and seasons ( $\mathrm{F}=0.690, \mathrm{P}=0.526$ ) (Figure 4 and Table 3 ). Penilia avirostris presented the highest relative abundance (87\%) (with an average of $52 \pm 688$ ind. $\mathrm{m}^{-3}$ ) and frequency of occurrence (71\%) among all the Cladocera species found during the sampling period. The richness ranged from 1 (June, July, November 2010; January, February and March 2011; February, March and June 2013) to 4 (February 2010) (Figure 5). Shannon diversity ranged from a minimum of 0.24 in February 2010 to a maximum of 0.64 in May 2010 with an average of $0.48 \pm 0.13$ bits.ind $^{-1}$. The equitability varied from a minimum of 0.2 in February 2010 (summer) to a maximum of 0.9 in December 2013 (summer) with an average of $0.51 \pm 0.22$ (Table 6 ). The cluster analysis of the monitored stations as a function of the space-time variation of the zooplankton showed three groups. Group A was very homogeneous because it was formed only by samples of flood tides in winter. The most heterogeneous Group B was composed of ebb and flood tide samples in
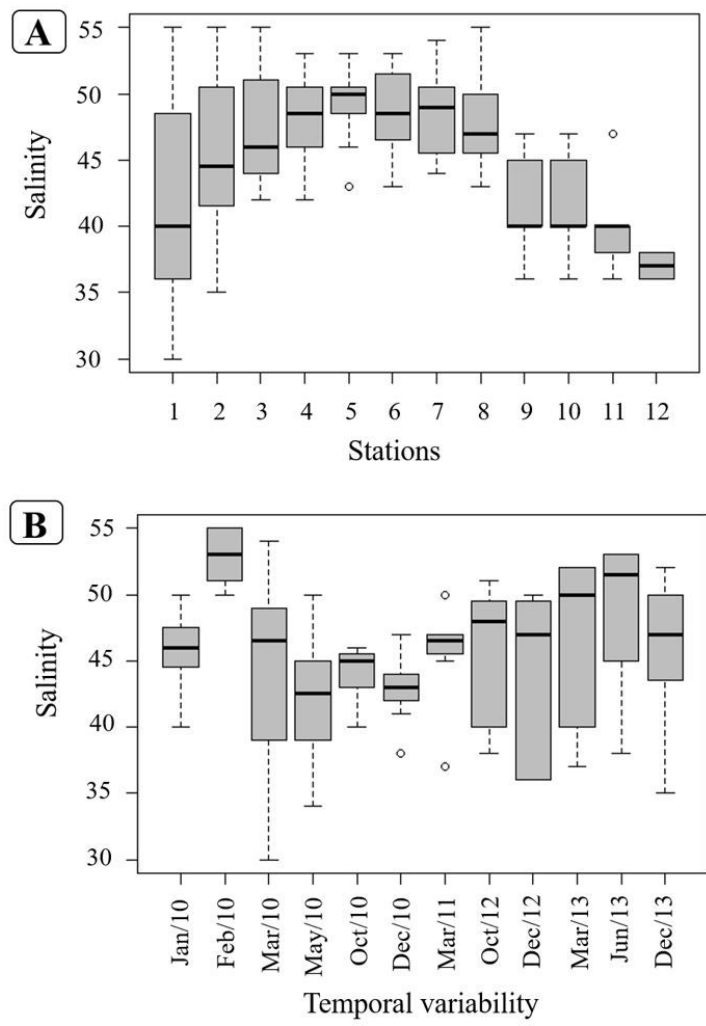

Figure 4. BoxPolt of salinity presented from means and standard deviation, spatial variation (A) and temporal variation (B). 
Table 3. Comparison of temperature in different collection stations and seasons in Araruama Lagoon. From the ANOVA statistical test. Df (degrees of freedom); Sum of sq (Sum of squares); Mean Sq (Mean of squares); F value (value on the F distribution); $\operatorname{Pr}(>\mathrm{F})(\mathrm{p}-\mathrm{value}$ for F statistics).

\begin{tabular}{cccccc}
\hline ANOVA & Df & Sum Sq & Mean Sq & F value & $\operatorname{Pr}(>\mathbf{F})$ \\
\hline Months & 12 & 1.0907 & 0.09089 & 126.26 & $<2 \mathrm{e}-16^{* * *}$ \\
Season & 1 & 0.0428 & 0.04278 & 59.44 & $8.65 \mathrm{e}-12^{* * *}$ \\
Months vs Season & 12 & 0.0731 & 0.00609 & 8.46 & $6.53 \mathrm{e}-11^{\cdots \cdots}$ \\
Residuals & 102 & 0.0734 & 0.00072 & & \\
\hline
\end{tabular}

Table 4. Comparison of salinity in different collection stations and seasons in Araruama Lagoon. From the ANOVA statistical test. Df (degrees of freedom); Sum of sq (Sum of squares); Mean Sq (Mean of squares); F value (value on the F distribution); $\operatorname{Pr}(>\mathrm{F})(\mathrm{p}-\mathrm{value}$ for F statistics).

\begin{tabular}{cccccc}
\hline ANOVA & Df & Sum Sq & Mean Sq & F value & $\operatorname{Pr}(>\mathbf{F})$ \\
\hline Months & 1 & 112.7 & 112.70 & 8.678 & $0.00408^{* *}$ \\
Season & 11 & 830.9 & 75.54 & 5.816 & $4.46 \mathrm{e}-07^{* * *}$ \\
Months vs Season & 11 & 1313.0 & 119.37 & 9.191 & $6.90 \mathrm{e}-11^{\cdots * *}$ \\
Residuals & 92 & 1194.9 & 12.99 & \\
\hline
\end{tabular}

Table 5. Comparison of cladocera abundance in different tides and seasons in Araruama Lagoon. From the ANOVA statistical test. Df (degrees of freedom); Sum of sq (Sum of squares); Mean Sq (Mean of squares); F value (value on the F distribution); $\operatorname{Pr}(>\mathrm{F})(\mathrm{p}-\mathrm{value}$ for F statistics).

\begin{tabular}{cccccc}
\hline & Df & Sum Sq & Mean Sq & F value & $\operatorname{Pr}(>\mathbf{F})$ \\
\hline Tide & 2 & 15.56 & 7.830 & 1.807 & 0.219 \\
Season & 3 & 6.04 & 2.014 & 0.465 & 0.714 \\
Tide vs Season & 2 & 5.98 & 2.991 & 0.690 & 0.526 \\
Waste & 9 & 39.00 & 4.334 & & \\
\hline
\end{tabular}

Table 6. Rich (S) Equitability (J') and Diversity of Shannon index (H'), from the Cladocera assemblage of Araruama Lagoon (Only stations 11 and 12 presented results because Cladocera was not found in the other stations).

\begin{tabular}{ccccc}
\hline Months and Years & Sample & S & J' & H' (loge) \\
\hline Feb.2010 & 12 & 4 & 0.3004 & 0.4165 \\
Feb.2010 & 11 & 3 & 0.2267 & 0.2491 \\
Mar.2010 & 12 & 3 & 0.3973 & 0.4365 \\
Mar.2010 & 11 & 3 & 0.3483 & 0.3826 \\
May.2010 & 12 & 3 & 0.5878 & 0.6458 \\
Dec.2010 & 12 & 3 & 0.5463 & 0.6002 \\
Dec.2010 & 11 & 2 & 0.8454 & 0.586 \\
Feb.2011 & 12 & 3 & 0.4805 & 0.5279 \\
Jun.2013 & 12 & 2 & 0.4798 & 0.3326 \\
Dec.2013 & 12 & 2 & 0.9171 & 0.6357
\end{tabular}

winter, summer and autumn. Group C was the largest and composed by $90 \%$ of flood tide samples, but seasonality intervals were found in all stations (Figure 6). In Group A the similarity was 47.06 with the highest contribution of E. spinifera (100\%). In Group B the similarity was 42.32 with the highest contribution of $P$. avirostris (99.39\%). In Group $C$ the similarity was 46.39 with a large contribution from P. avirostris (93.47\%). The dissimilarity between Groups
C and A was $98.12 \%$. The species that most contributed to this were: Penilia avirostris (82.56\%) and Pseudevadne tergestina (95.29\%). The dissimilarity between Groups C and $B$ was $89.75 \%$. And the species that contributed were: Penilia avirostris (83.09\%) and Pseudevadne tergestina (95.71\%). The dissimilarity between Groups A and B was (95.19\%). The species that contributed were: P. avirostris (61.74\%) and E. spinifera (99.33\%). 


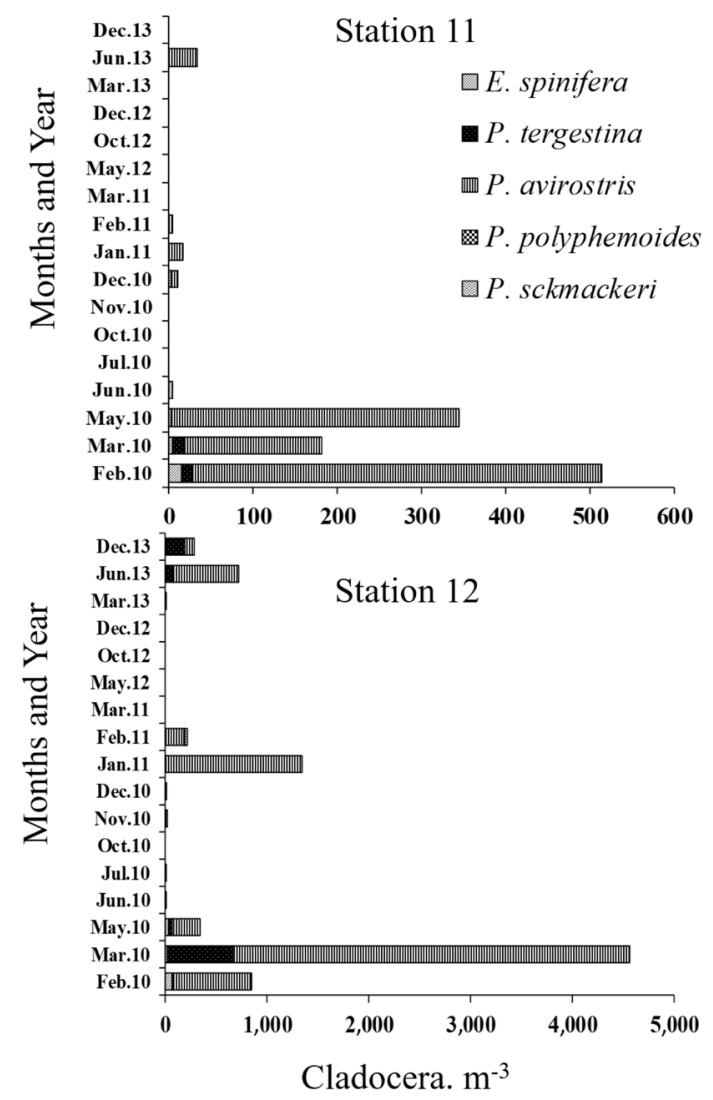

Figure 5. Cladocera Assemblage of Araruama Lagoon from January 2010 to December 2013. Stations 11 and 12 with different scales. E. spinifera (black and white lines arranged laterally); P. tergestina (black with small white spots); P. avitostris (vertical black and white lines); P. polyphemoides (chess pattern); P. sckmackeri (black and white lines waved horizontally).

\section{Discussion}

Cladocera showed a spatial distribution limitation, found only in the two stations closest to the sea where the salinity and temperature of the lagoon is more similar to the sea (Rosa and Batista, 2020). Although the gradient of salinity and temperature showed no significant correlation to Cladocera abundance, no individuals were encountered in stations where salinity and temperature were higher. These results corroborate with the study by Rosa et al. (2020), which shows a decrease in the density and richness of the zooplankton community in the inner parts of the lagoon. In the temporal variation, salinity and temperature varied little over the years, therefore, this variation of Cladocera seems to be more related to seasonality (present or absent) (Sommer and Sommer, 2006).

The absence of Cladocerans in the internal stations of the lagoon may be associated with high salinity. Although the linear regression did not show significant results due to the low frequency of occurrence of the group, this hypothesis cannot be discarded, since this group may not be able to maintain osmotic regulation in hypersaline environments (Rosa et al., 2016; Coutinho et al., 1999). The study conducted by Rosa et al. (2016) in Araruama lagoon, reported that fish larvae and eggs may be under osmotic stress, especially in places where salinity is higher. This stress may also be occurring within the Cladocera in the innermost stations (station 1 to 10 ), causing mortality of individuals of different species of Cladocera. Coutinho et al. (1999) showed that the low plankton density in the Araruama lagoon is correlated with the increase of the salinity that influences the planktonic community.

The average temperature of the lagoon recorded in this study is quite high when compared with other Cladocera studies (Rose et al. 2004; Miyashita et al. 2011; Baker, 1938; Ramirez, 1981). However, high

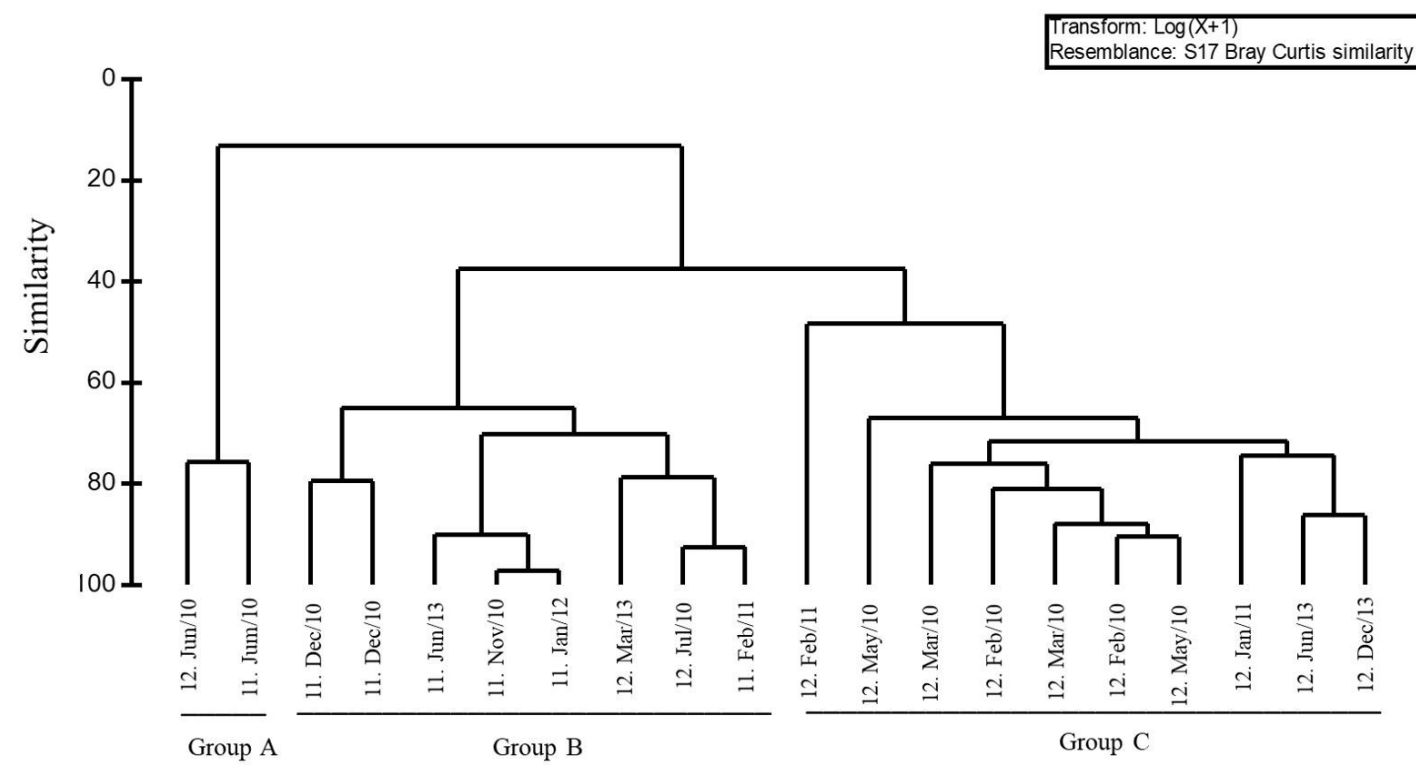

Figure 6. Cluster analysis (Bray Curtis Similarity) of the stations sampled (stations 11 and 12 in front of the date, followed by the month number and then supporting the year) during the monitoring of the Araruama lagoon aquatic biota, in function of the zooplankton assemblage richness and abundance. 
temperature values were also found in other studies in the Araruama lagoon (Rosa et al., 2016, 2020; Rosa and Batista, 2020; Souza et al., 2003). Although we did not find significant results in linear regression due to low frequency of occurrence, temperature could also be limiting the entry of Cladocera into the lagoon. According to Põllupüü et al. (2010), space-time variation showed significant results in the Cladocera population in terms of survival, evident in parthenogenetic individuals both related to water temperature.

The present work found a number of species similar to the work of Miyashita et al. (2011) who also found four taxa in Ubatuba, on the coast of Brazil. The diversity observed in this study, however, was low compared to the work of Nunes (2010) who found mean values of 0.62 in spring, in the state of Espírito Santo in Brazil. Both studies (Miyashita et al., 2011; Nunes 2010) were carried out in a coastal region, i.e. in the sea with salinity and slightly lower temperature, making their results comparable to our study with Cladoceras only found in stations close to the sea, where salinity, temperature and the tide is almost equal to sea conditions.

The temporal variation of the Cladocera assemblage is characterized as extremely seasonal: higher peaks in autumn and smaller peaks in summer and winter, different from several related studies in the Baltic Sea, where the peaks occurred in spring, reaching highest densities in summer and disappearing in autumn while, the present work found the lowest seasonal peak in spring (Viitasalo et al., 1995; Möllmann et al., 2005; Põllupüü et al., 2010).

The greatest abundance of $P$. avirostris, reported as the most dominant Cladocera on the Brazilian coast (Resgalla Júnior and Montú, 1993; Vega-Pérez, 1993), was found in the summer just as in the work of Marazzo and Valentin (2004), conducted in Guanabara Bay (Rio de Janeiro-Brazil) in 1985. P. avirostris is cosmopolitan, found in tropical and subtropical waters (Johns et al., 2005), with wide distribution on the Brazilian coast (Rocha, 1982), making this result not highly surprising.

In the present study Pleopis polyphemoides presented low density and frequency of occurrence, this result corroborates the study of Ramirez (1981) which indicates that this species is found in brackish and cold waters. In the present study the species occurred only in summer as in the work of Onbé (1985), in the Japanese Inner Sea where the species usually occurs in spring until the beginning of summer.

The species Pleopis schmackeri was found in the present study, however, due to their low abundance and rare presence in tropical and coastal waters, knowledge on their ecological characteristics is still scarce (Marazzo, 2002). Their incidence has been described in waters from the South China Sea to the Northeast of Honshu (Japan) and there are sporadic records for Aqaba Bay (Red Sea) and Madagascar (Indian Ocean). In Brazilian waters, some records were made by: Rocha (1985) on the coast of São Paulo; Resgalla Júnior and Montú (1993) on the southern coast; Marazzo (2002); in the Guanabara Bay, Rio de Janeiro; Resgalla Júnior et al. (2008; Resgalla Júnior, 2011) on the coast of Santa Catarina and in the southern coast among other works; by Monteiro-Ribas et al. (2013) in Rio das Ostras, Rio de Janeiro.

The results show that the tide has no significance in the Cladocera assemblage. In estuaries, the higher density is influenced by the tide, revealing a zooplankton community with greater diversity at high tide (Melo et al., 2008). In a certain way, when the tide is full, the salinity decreases (Rosa et al., 2016) and this is a factor that influences the density of the Cladocera assemblage (Della Croce and Venugopal, 1972; Marazzo and Valentin, 2004). However, the present study did not find similar results, probably due to the seasonality of the Cladocera assemblage, being absent even at high tide conditions in most stations.

Finally, another factor that may be affecting the entry of Cladocera into the inner part of the lagoon is the discharge of sewage in natura (Carvalho et al., 2014), because the study of Elmoor- Elmoor-Loureiro (2004) indicates that contamination by toxic agents occurs. A polluted environment can have a low food quality, i.e. many cyanobacteria and few diatomaceae, as for example occurs in the Pitanguinha Lagoon which is also a hypersaline lagoon located in the state of Rio de Janeiro (Silva et al., 2005).

\section{Conclusions}

The salinity and temperature of the lagoon seem to be the factors that influence the dynamics of the assemblages in terms of spatial variation, acting as a barrier preventing the entry of Cladocera in the inner parts of the lagoon where these environmental parameters present higher values than in the sea. In terms of temporal variation, salinity and temperature do not seem to be the main environmental parameters that influence the dynamics of the Cladocera assemblage, as they varied little over the years. Therefore, more research is required on the possible impacts of other factors (such as anthropogenic effects) that might be influencing the Cladocera of this hypersaline lagoon.

\section{Acknowledgements}

The authors wish to thank the Consórcio Intermunicipal Lagos São João, which funded the study, and Prolagos, which analyzed the abiotic data at the study location. Additionally, we wish to thank Yasmina Shah Esmaeili for the English revision of the manuscript.

\section{References}

BAKER, H.M., 1938. Studies on the Cladocero of Monterey Bay. Proceedings of the California Academy of Sciences, vol. 29, no. 23, pp. 311-365.

BOLTOVSKOY, D.C., 1981. Atlas del zooplancton del Atlântico Sudoccidental metodos de trabajo com el zooplancton marine. Mar del Plata: INIDEP, $936 \mathrm{p}$.

BOLTOVSKOY, D.C., 1999. South Atlantic zooplankton. Leiden: Backhuys Publishers, 1706 p. 
BUSKEY, E.J., WYSOR, B. and HYATT, C., 1998. The role of hypersalinity in the persistence of the Texas 'brown tide' in the Laguna Madre. Journal of Plankton Research, vol. 20, no. 8, pp. 1553-1565. http:// dx.doi.org/10.1093/plankt/20.8.1553.

CARVALHO, A.P.A.M., COSTA, R.S. and ROSA, J.C.L., 2014 Eutrophication and introduction of exotic species in hypersaline estuary. In: Proceedings of IV Seminário Regional Sobre Gestão de Recursos Hídricos, 28-30 Outubro 2014, Campos dos Goytacazes, RJ. Rio de Janeiro: UPEA/IFF, 13 p. CD-ROM.

CASTRO, M.S., BONECKER, A.C.T. and VALENTIN, J.L., 1999. Ichthyoplankton of a permanently hypersaline coastal lagoon: lagoa de Araruama, Brazil. Journal of Tropical Ecology, vol. 40, no. 2, pp. 221-227.

CLARKE, K.R. and GORLEY, R.N., 2015. PRIMER v7: user manual/ tutorial. Plymouth: PRIMER-E.

COUTINHO, R., RIBEIRO, P., KJERFVE, B., KNOPPERS, B., MUEHE, D. and VALENTIN, J.L., 1999. Araruama, uma lagoa ameaçada. Ciência Hoje, vol. 25, pp. 24-31.

DEBASTIANI-JÚNIOR, J.R., ELMOOR-LOUREIRO, L.M.A. and NOGUEIRA, M.G., 2016. Habitat architecture influencing microcrustaceans composition: a case study on freshwater Cladocera (Crustacea Branchiopoda). Brazilian Journal of Biology = Revista Brasileira de Biologia, vol. 76, no. 1, pp. 93-100. http:// dx.doi.org/10.1590/1519-6984.13514. PMid:26909628.

DELLA CROCE, N. and VENUGOPAL, P., 1972. Distribution of marine cladocerans in the Indian Ocean. Marine Biology, vol. 15, no. 2, pp. 132-138. http://dx.doi.org/10.1007/BF00353641.

ELMOOR-LOUREIRO, L.M.A., 2004. Morphological abnormalities in the cladoceran Ilyocryptus spinifer (Apipucos Reservoir, Pernambuco state, Brazil). Brazilian Journal of Biology = Revista Brasileira de Biologia, vol. 64, no. 1, pp. 53-58. http://dx.doi. org/10.1590/S1519-69842004000100007. PMid:15195364.

FIELD,J.G., CLARKE, K.R. and WARWICK, R.M., 1982. A practical strategy for analysing multispecies distribution patterns. Marine Ecology Progress Series, vol. 8, pp. 37-52. http://dx.doi.org/10.3354/meps008037.

HAYASHI-MARTINS, L.H., MANSANO, A.S., HISATUGO, K.F., ROCHA, O. and SELEGHIM, M.H.R., 2017. Avaliação "in vitro" do potencial baterívoro de três espécies de Cladocera de ocorrência tropical e subtropical. Brazilian Journal of Biology = Revista Brasileira de Biologia, vol. 77, no. 4, pp. 840-847. http://dx.doi. org/10.1590/1519-6984.02716. PMid:28355388.

JOHNS, D.G., EDWARDS, M., GREVE, W. and SJOHN, A.W.G., 2005. Increasing prevalence of the marine cladoceran Penilia avirostris (Dana, 1852) in the North Sea. Helgoland Marine Research, vol. 59, no. 3, pp. 214-218. http://dx.doi.org/10.1007/s10152-005-0221-y.

LEGENDRE, P. and LEGENDRE, L., 1998. Numerical ecology. Amsterdam: Elsevier Science, 853 p.

MARAZZO, A. and VALENTIN, J.L., 2004. Reproductive aspects of marine cladocerans Penilia avirostris and Pseudevadne tergestina (Crustacea, Branchiopoda) in the outer part of Guanabara Bay, Brazil. Brazilian Journal of Biology = Revista Brasileira de Biologia, vol. 64, no. 3A, pp. 543-549. http://dx.doi.org/10.1590/S151969842004000300017. PMid:15622851.

MARAZZO, A., 2002. Record of Pleopis schmacheri (Poppe) (Branchiopoda, Onychopoda) in the Guanabara Bay, Rio de Janeiro, Brasil. Revista Brasileira de Zoologia, vol. 19, suppl. 1, pp. 335-336. http://dx.doi.org/10.1590/S0101-81752002000500027.

MELO, P.A.M.C., NEUMANN-LEITÃO, S., GUSMÃO, L.M.O. and PORTO NETO, F.F., 2008. Variação nictemeral do macrozooplâncton na Barra Orange - Canal de Santa Cruz, eEstado de Pernambuco (Brasil). Revista Brasileira de Engenharia de Pesca, vol. 3, no. 2, pp. 30-49.

MIYASHITA, L.K., GAETA, S.A. and LOPES, R.M., 2011. Life cycle and reproductive traits of marine podonids (Cladocera, Onychopoda) in a coastal subtropical área. Journal of Plankton Research, vol. 33, no. 5, pp. 779-792. http://dx.doi.org/10.1093/plankt/fbq147.

MÖLLMANN, C., KORNILOVS, G., FETTER, M. and KÖSTER, F.W., 2005. Climate, zooplankton, and pelagic fish growth in the central Baltic Sea. ICES Journal of Marine Science, vol. 62, no. 7, pp. 1270-1280. http://dx.doi.org/10.1016/j.icesjms.2005.04.021.

MONTEIRO-RIBAS, W., ROCHA-MIRANDA, F., ROMANO, R.C. and QUINTANILHA, J., 2006. Larval development of Brachidontes solisianus (Bivalvia, Mytilidae): with notes on differences between its hinge system and that of the mollusk Perna perna. Brazilian Journal of Biology = Revista Brasileira de Biologia, vol. 66, no. 1A, pp. 109-116. http://dx.doi.org/10.1590/S151969842006000100014. PMid:16680313.

MONTEIRO-RIBAS, W.M., FREITAS, I.S. and ROSA, J.C.L., 2013. Record of Pleopis schmackeri (Poppe) Branchiopoda in Rio das Ostras, Rio de Janeiro, Brazil. Biotemas, vol. 64, no. 2, pp. 149-156. http:// dx.doi.org/10.5007/2175-7925.2013v26n1p201.

NUNES, R.A., 2010. Composição e estrutura da comunidade zooplanctônica de um estuário tropical (Espírito Santo, Brasil). Vitória: Universidade Federal do Espírito Santo, 69 p. Dissertação de Mestrado em Oceanografia Ambiental.

ONBÉ, T., 1985. Seasonal fluctuations in the abundance of populations of marine cladocerans and their resting eggs in the Inland Sea of Japan. Marine Biology, vol. 87, pp. 83-88. http:// dx.doi.org/10.1007/BF00397009.

PEREIRA, L.F.M., 2007. A gestão participativa no caso do saneamento da região dos Lagos, Rio de Janeiro. Revista Discente Expressões Geográficas, no. 3, pp. 10-41. http://dx.doi.org/10.1007/ BF00397009.

PÕLLUPÜÜ, M., SIMM, M. and OJAVEER, H., 2010. Life history and population dynamics of the marine cladoceran Pleopis polyphemoides (Leuckart) (Cladocera, Crustacea) in a shallow temperate Pärnu Bay (Baltic Sea). Journal of Plankton Research, vol. 32, no. 10, pp. 1459-1469. http://dx.doi.org/10.1093/plankt/fbq063.

RAMIREZ, F.C., 1981. Cladocera. In: D. BOLTOVSKOY, ed. Atlas del Zooplancton del Atlántico Sudoccidental y métodos de trabajo con el zooplancton marino. Mar del Plata: INIDEP, pp. 538-542.

RESGALLA JÚNIOR, C. and MONTÚ, M., 1993. Cladóceros marinhos da plataforma continental do Rio Grande do Sul, Brazil. Nauplius, vol. 1, pp. 63-79.

RESGALLAJÚNIOR, C., SOUZA, V. G. C. DE, RÖRIG, L. R., and SCHETTINI, C. A. F., 2008. Spatial and temporal variation of the zooplankton community in the area of influence of the Itajaí-açu River, SC (BRAZIL). Brazilian Journal of Oceanography, vol. 56, no. 3, pp. 211-224. https://doi.org/10.1590/S1679-87592008000300006.

RESGALLA JÚNIOR, C., 2011. The holoplankton of the Santa Catarina coast, southern Brazil. Anais da Academia Brasileira de Ciências, vol. 83, no. 2, pp. 575-588. http://dx.doi.org/10.1590/S000137652011000200017. PMid:21670880.

ROCHA, C.E.F., 1982. Distribution of the marine cladoceran (Crustacea, Branchiopoda) of Santos, Brazil. Boletim de Zoologia, vol. 7, no. 1, pp. 155-169.

ROCHA, C.E.F., 1985. The occurence of Pleopis schmackeri (Poppe) in Southern Atlantic and other marine cladocerans on the Brazilian cost. Crustaceana, vol. 49, no. 1-3, pp. 202-204. http:// dx.doi.org/10.1163/156854085X00459.

ROSA, J.C.L. and BATISTA, L.L., 2020. Spatial and temporal variability of the zooplankton community at Araruama Lagoon. Biotemas, vol. 33, no. 3, pp. 1-10. http://dx.doi.org/10.5007/21757925.2020.e70246.

ROSA, J.C.L., ALBERTO, M.D., MONTEIRO-RIBAS, W.M., NEVES, M.H.C.B. and FERNANDES, L.D., 2016. Spatial variability in the icthyoplankton structure of a subtropical hypersaline lagoon. 
Brazilian Journal of Oceanography, vol. 64, no. 2, pp. 149-156. http://dx.doi.org/10.1590/S1679-87592016109406402.

ROSA, J.C.L., BATISTA, L.L. and MONTEIRO-RIBAS, W.M., 2020. Tracking of spatial changes in the structure of the zooplankton community according to multiple abiotic factors along a hypersaline lagoon. Nauplius, vol. 28, e2020012. http://dx.doi. org/10.1590/2358-2936e2020012.

ROSE, K., ROFF, J.C. and HOPCROFT, R.R., 2004. Production of Penilia avirostris in Kingston Harbour, Jamaica. Journal of Plankton Research, vol. 26, no. 6, pp. 605-615. http://dx.doi.org/10.1093/ plankt/fbh059.

SILVA, L.H.S., DAMAZIO, C.M. and IESPA, A.A.C., 2005. Identificação de cianobactéricas em sedimentos da Lagoa Pitanguinha, estado do Rio de Janeiro, Brasil. Anuário do Instituto de Geociências, vol. 28, no. 1, pp. 92-100.

SILVA, W.M. and PERBICHE-NEVES, G., 2017. Trends in freshwater microcrustaceans studies in Brazil between 1990 and 2014. Brazilian Journal of Biology = Revista Brasileira de Biologia, vol. 77, no. 3, pp. 527-534. http://dx.doi.org/10.1590/1519-6984.17915. PMid:27925015.
SOMMER, U. and SOMMER, F., 2006. Cladocerans versus copepods: the cause of contrasting top-down controls on freshwater and marine phytoplankton. Oecologia, vol. 147, no. 2, pp. 183-194. http://dx.doi.org/10.1007/s00442-005-0320-0.

SOUZA, M.F.L., KJERFVE, B., KNOPPERS, B., LANDIM DE SOUZA, W.F. and DAMASCENO, R.N., 2003. Nutrient budgets and trophic state in a hypersaline coastal lagoon: lagoa de Araruama, Brazil. Estuarine, Coastal and Shelf Science, vol. 57, no. 5-6, pp. 843-858. http://dx.doi.org/10.1016/S0272-7714(02)00415-8.

VEGA-PÉREZ, L.A., 1993. Estudo do zooplâncton da região de Ubatuba, Estado de São Paulo. Boletim do Instituto Oceanográfico, vol. 10, pp. 65-84.

VIITASALO, M., VUORINEN, I. and SAESMAA, S., 1995. Mesozooplankton dynamics in the northern Baltic Sea: implications of variations in hydrography and climate. Journal of Plankton Research, vol. 17, no. 10, pp. 1857-1878. http://dx.doi. org/10.1093/plankt/17.10.1857.

WOOLDRIDGE, T.H. and DEYZEL, S.H.P., 2009. Temperature and salinity as abiotic drivers of zooplankton community dynamics in the Great Berg Estuary. Transactions of the Royal Society of South Africa, vol. 64, no. 2, pp. 219-237. http://dx.doi. org/10.1080/00359190909519254. 